\title{
DISTRIBUSI UNSUR MAKRO DAN MIKRO DALAM ABU GUNUNG MERAPI YOGYAKARTA
}

\author{
Theresia Rina Mulyaningsih ${ }^{1}$, Iman Kuntoro dan Alfian
}

(Diterima tanggal: 03-01-2011; Disetujui tanggal: 18-05-2011)

\begin{abstract}
ABSTRAK
DISTRIBUSI UNSUR MAKRO DAN MIKRO DALAM ABU GUNUNG MERAPI YOGYAKARTA. Telah dilakukan analisis kandungan unsur dalam abu Gunung Merapi pasca erupsi Oktober - Nopember 2010 dengan teknik analisis aktivasi neutron (AAN). Pengambilan sampling dilakukan oleh peneliti PTAPB-BATAN pada tanggal 9 dan 10 Nopember 2010 di 10 titik sampling. Lokasi sampling sebanyak 4 titik di Kabupaten Sleman, 1 titik di Kabupaten Magelang, 3 titik di Kabupaten Klaten dan 2 titik di Kabupaten Boyolali. Sampel abu vulkanik dikeringkan,diayak lolos saring 200 mesh dan ditimbang $30-50 \mathrm{mg}$ dalam vial polietilen. Iradiasi dilakukan pada fluks neutron termal 1013 n.cm-2.det-1 di fasilitas iradiasi Reaktor Serba Guna GA. Siwabessy, Serpong. Pencacahan cuplikan pasca iradiasi dilakukan dengan detektor resolusi tinggi HPGe yang digabungkan dengan penganalisis puncak multi saluran. Analisis data dilakukan dengan perangkat lunak GENIE 2000 dan k0-IAEA. Hasil analisis menunjukkan bahwa unsur dalam abu vulkanik terdiri atas unsur makro (dalam persen) Al 10,45-13,37; Fe 4,44-8,79; Na 2,553,35; Ca 1,03-8,82; Mg 0,61-1,75; Ti 0,31-0,58; dan Mn 0,12-0,17, unsur mikro ( $<500$ mg/kg) Ba, Zn, Sb, Eu, $\mathrm{U}, \mathrm{Hg}, \mathrm{Hf}, \mathrm{Ce}, \mathrm{Yb}, \mathrm{La}, \mathrm{Sc}, \mathrm{Co}, \mathrm{Cs}, \mathrm{Dy}, \mathrm{Tb}, \mathrm{Lu}, \mathrm{Rb}$ dan V. Distribusi unsur-unsur ini hampir merata di semua titik lokasi sampling kecuali untuk unsur $\mathrm{As}, \mathrm{Zn}$ dan $\mathrm{Cr}$ hanya ditemukan di beberapa lokasi sampling. Adanya logam berat $\mathrm{Hg}$, As, dan $\mathrm{Cr}$, perlu mendapat perhatian khusus dalam kaitan pemanfaatan abu vulkanik dalam kehidupan masyarakat yang mempunyai dampak terhadap kesehatan manusia dan lingkungan. Abu vulkanik dapat digunakan sebagai bahan bangunan, bahan keramik dan lahan pertanian.
\end{abstract}

\begin{abstract}
DISTRIBUTION OF MACRO AND MICRO ELEMENTS IN THE ASH OF Mt. MERAPI YOGYAKARTA. The elements content in the ash of Mt. Merapi after eruption on October - November 2010 have been analyzed by neutron activation analysis technique. Sampling was taken by researcher of PTAPB BATAN Yogyakarta on the 9 and 10 of November 2010 in 10 location points. Four points in Sleman Regency, 1 point in Magelang Regency, 3 points in Klaten Regency and 2 points in Boyolali Regency. The samples of the volcanic ash were dried, filtered by 200 meshes and weighed 30-50 mg in the polyethylene vial. Irradiation have been done at thermal neutron flux of about 1013 n.cm-2.det-1 in the irradiation facility of Multi Porpuse Reactor GA. Siwabessy in Serpong. Counting of irradiated samples have been done by a high resolution HPGe detector couple to multi channal analyzer. Data have been analyzed by GENIE 2000 and k0-IAEA sofware. The results shows that elements content in the volcanic ash are macro elements (in percent) of $\mathrm{Al} \mathrm{10,45-13,37;} \mathrm{Fe} 4,44-8,79 ; \mathrm{Na} \mathrm{2,55-3,35;} \mathrm{Ca} \mathrm{1,03-8,82;} \mathrm{Mg}$ 0,61-1,75; Ti 0,31-0,58; and Mn 0,12-0,17 and micro elements (<500 mg/kg) of Ba, Zn, Sb, Eu, U, Hg, Hf, Ce, Yb, La, Sc, Co, $C s, D y, T b, L u, R b$ and $V$. Distribution of these elements are nearly similar at all of the sampling location points except for the elements of $\mathrm{As}, \mathrm{Zn}$ and $\mathrm{Cr}$ that were found out only at the certain sampling locations. The existence of heavy elements of $\mathrm{Hg}$, As and Cr shall be paid by high attention in relation to the utilization of the ash or sands by the publics due to its impact to the health and environment. Volcanic ash can be used as building material, material ceramics and agricultural land.
\end{abstract}

Keywords: element, volcanic ash, Mt. Merapi, eruption, NAA.

\section{PENDAHULUAN}

Gunung Merapi sudah dikenal sebagai gunung berapi yang sangat aktif dengan karakteristik khusus yaitu menyemburkan awan panas dan menimbulkan lahar dingin di saat hujan. Gunung Merapi terletak di bagian tengah Pulau Jawa dan merupakan salah satu gunung

\footnotetext{
${ }^{1}$ Pusat Teknologi Bahan Industri Nuklir BATAN Kawasan Puspiptek Gedung No. 43, Serpong, Tangerang, Banten 15310 e-mail : thrinam batan.go.id
} 
api teraktif di Indonesia. Lereng sisi selatan berada dalam daerah Kabupaten Sleman, Provinsi Daerah Istimewa Yogyakarta, dan sisanya berada dalam wilayah Provinsi Jawa Tengah, yaitu Kabupaten Magelang di sisi barat, Kabupaten Boyolali di sisi utara dan timur serta Kabupaten Klaten di sisi tenggara [1].

Gunung ini pada bulan April 2006 telah mengeluarkan erupsi dan meletus pada 26 Oktober 2010. Letusan terjadi dengan semburan lava dalam jumlah besar diikuti oleh hujan abu vulkanik ke daerah sekitar gunung berapi. Hujan abu vulkanik ini tersebar ke daerah sekitar hingga mencapai luasan dalam radius lebih dari $20 \mathrm{~km}$. Dampak langsung dari abu vulkanik ini adalah menimbulkan gangguan pernafasan dan merusak lahan pertanian dan hunian yang berada di areal tersebut. Penumpukan abu vulkanik berupa pasir dan batuan mencapai jumlah lebih dari 1.500.000 ton. Pada masa pasca letusan yaitu masa pemulihan, masyarakat membangun kembali tempat hunian dan lahan pertanian dengan menyingkirkan dan memanfaatkan pasir dan batuan tersebut sebagai bahan bangunan.

Hasil Penelitia abu vulkanik Gunung Merapi yang diambil pada Juli 2008 mengandung Al, $\mathrm{Mg}$, Si dan Fe dengan komposisi 1,8-15,9\% Al, 0,1-2,4\% Mg, 2,6-28,7\% Si dan 1,4-9,3\% Fe. [2] Sedangkan penelitian yang telah dilakukan terhadap abu vulkanik pasca erupsi 2010 menggunkan metode analisis aktivasi neutron cepat memberikan hasil bahwa abu vulkanik mengandung $\mathrm{Al}, \mathrm{Mg}, \mathrm{Si}$ dan $\mathrm{Fe}$ dengan komposisi 0,22-0,35\% Al, 0,08-0,26\% $\mathrm{Mg}, 0,65-1,90 \%$ Si dan 0,56-1,54\% Fe. [3]
Letusan Merapi dapat mendatangkan bahaya karena semburan lahar panas dan banjir lahar dingin, tetapi sekaligus memberi manfaat bagi penduduk yang tinggal di sekitar lereng Merapi. Material vulkanik yang dikeluarkan dapat digunakan sebagai bahan bangunan dan dapat menyuburkan tanah pertanian yang ada di sekitarnya. Agar material vulkanik tersebut dapat dimanfaatkan secara optimal maka diperlukan data unsur-unsur yang terkandung di dalam material tersebut.

Penelitian ini dilakukan untuk mengetahui distribusi dan kadar unsur dalam abu vulkanik pasca erupsi November 2010 dengan memanfaatkan teknologi nuklir yaitu teknik analisis aktivasi neutron (AAN). Hasil penelitian diharapkan dapat memberikan data unsur-unsur penting bagi kesehatan manusia, lingkungan dan memiliki nilai ekonomi, yang terkandung dalam pasir vulkanik Gunung Merapi. Data dapat digunakan sebagai masukan bagi masyarakat pengguna dan pengambil kebijakan dan sebagai tambahan data yang sudah terkumpul dengan metode atau teknik lain oleh peneliti lain.

\section{TATA KERJA}

\section{Pengambilan Sampel}

Sampel berupa abu vulkanik diambil di lokasi pada teras gedung kelurahan, sekolahan, puskesmas, koramil atau tenda pengungsi yang kosong. Dilakukan pada tanggal 9 dan 10 Nopember 2010 pukul 10.00-18.00. Lokasi pengambilan sampel pada radius $15-20$ km dari Gunung Merapi, sejumlah 10 titik sampling yang meliputi 4 titik di Kabupaten Sleman, 1 titik di Kabupaten Magelang, 3 titik di Kabupaten Klaten dan 2 titik di Kabupaten Boyolali (Gambar 1) dan Tabel 1. 


\section{Preparasi Sampel}

Sampel abu vulkanik dikeringkan, dihomogenkan dan diayak hingga lolos saring 200 mesh. Sampel abu ini kemudian ditimbang dengan neraca mikro dalam vial Low Density Poly Ethylene, LDPE. Berat sampel antara 20$50 \mathrm{mg}$. Sampel ini kemudian disusun sebagai target yang membentuk layer yang terdiri atas sampel, bahan acuan standar sebagai kontrol dan pemantau fluks neutron Al-0,1\% Au. Target ini disusun dalam kapsul iradiasi dan siap diiradiasi di sistem Rabbit reaktor nuklir
RSG GAS. Waktu iradiasi masing-masing 1 menit untuk analisis unsur $\mathrm{Al}, \mathrm{Ca}, \mathrm{Mn}$, $\mathrm{V}$, Ti dan $\mathrm{Mg}, 10$ menit untuk analisis $\mathrm{Na}$, As, $\mathrm{K}$ dan 60 menit untuk analisis La, Ba, $\mathrm{Zn}, \mathrm{Cs}, \mathrm{Rb}, \mathrm{Co}, \mathrm{Cr}, \mathrm{Sb}, \mathrm{Hg}$, Hf, Ce, Sc, Dy, $\mathrm{Eu}, \mathrm{Lu}, \mathrm{Yb}$, dan Tb. Sampel pasca iradiasi dicacah dengan spektrometri gamma dengan detektor germanium kemurnian tinggi HPGe yang dilengkapi dengan Genie 2000. Analisis kuantitatif dengan bantuan perangkat lunak k0-AAN IAEA.

Tabel 1. Lokasi Sampling Abu Vulkanik Merapi 2010

\begin{tabular}{|c|c|c|}
\hline Kode Lokasi/Koordinat & Lokasi Pengambilan & Jarak \\
\hline L-1(S 074159 E 1102643$)$ & Kecamatan Ngemplak- Kab. Sleman & $17 \mathrm{Km}$ \\
\hline L-2(S 073954 E 1102503$)$ & Pasar hewan Tegal, Kecamatan Pakem- Kab. Sleman & $15 \mathrm{~km}$ \\
\hline L-3(S 073913 E 11022 47) & Desa Wonokerto Kecamatan Turi- Kab Sleman & $14 \mathrm{~km}$ \\
\hline L-4(S 0739 07,5 E 11019 34,6) & Desa Lumbung Rejo, Kecamatan Tempel-Kab. Sleman & $17 \mathrm{~km}$ \\
\hline L-5(S 073635,1 E 11018 08,9) & Desa Jumoyo Kecamatan Salam-Kab. Magelang & $18,7 \mathrm{~km}$ \\
\hline L-6(S 073942,9 E 11024 20,3) & Desa Ngemplak Seneng, Kecamatan Manisrenggo, Klaten & $15 \mathrm{~km}$ \\
\hline L-7(S 0740 25,3 E 11030 30,1) & Desa Sukorini, Klaten & $17 \mathrm{~km}$ \\
\hline L-8(S 0740 25,3 E 11031 54,8) & Desa Sumukaton Kecamatan Karangnongko, Klaten & $20 \mathrm{~km}$ \\
\hline L-9(S 073523 E 11033 16,6) & Desa Keposong Kecamatan Musuk, Boyolali & $26 \mathrm{~km}$ \\
\hline L-10(S07 33 52,2 E 11032 15,8) & Desa Drajitan Kecamatan Musuk, Boyolali & $20 \mathrm{~km}$ \\
\hline
\end{tabular}




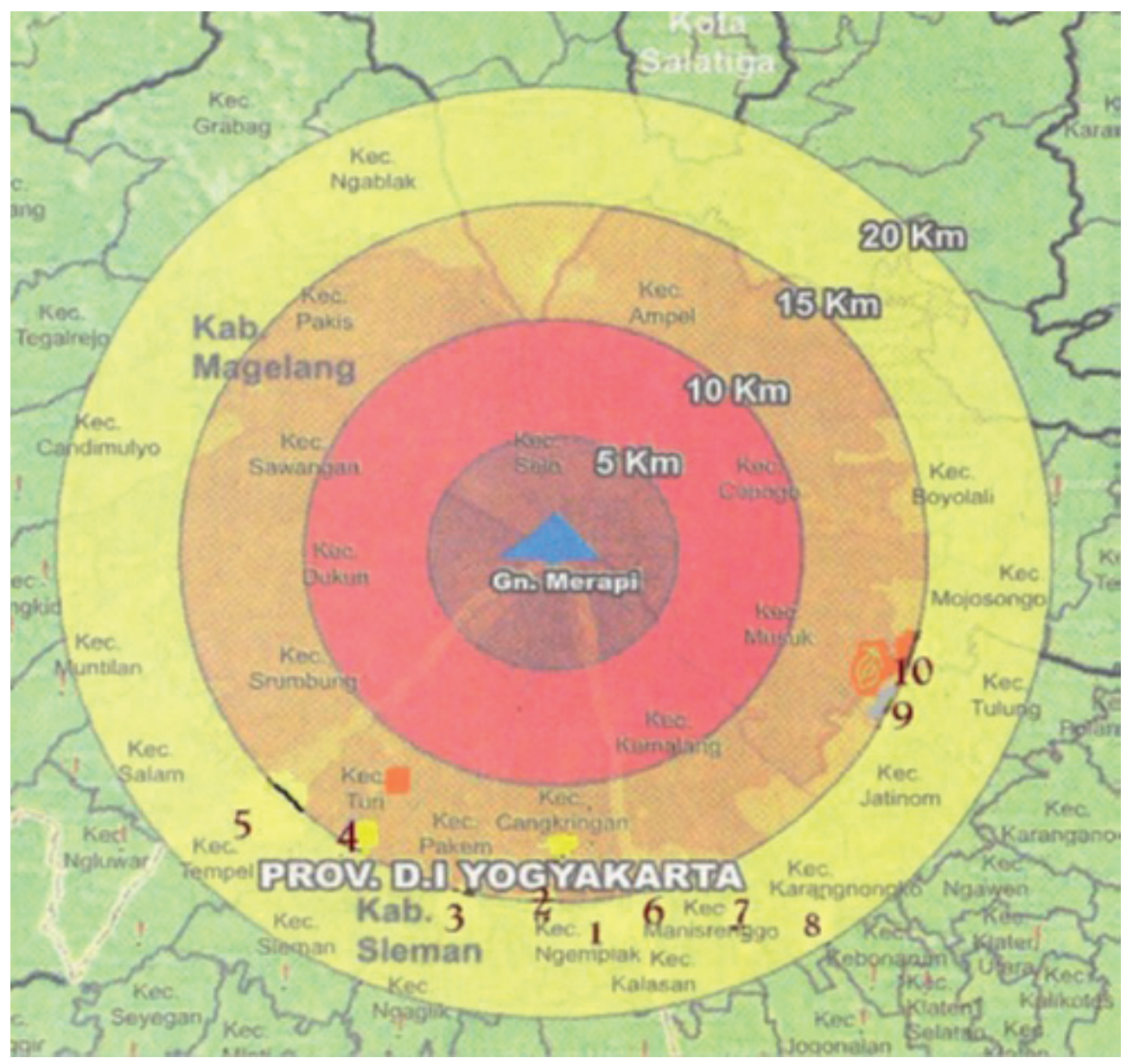

Gambar 1. Lokasi sampling abu vulkanik disekitar Gunung Merapi Yogyakarta

\section{HASIL DAN PEMBAHASAN}

Hasil analisis bahan acuan standar bersertifikat NIST SRM 2711a sebagai kontrol internal metode disajikan pada Tabel 1. Nilai hasil analisis bahan standar Montana soil di Laboratorium AAN dibandingkan dengan nilai dalam sertifikat untuk unsur-unsur yang dianalisis, memiliki nilai bias relatif lebih kecil dari 10\% dan dari hasil pengujian akurasi dan presisi metode dengan tingkat kepercayaan
95\%, memberikan hasil lolos pada kedua uji tersebut. Berdasarkan nilai u-test $<1,64$ berarti nilai hasil analisis dalam pengujian ini tidak berbeda secara signifikan dari nilai sertifikat, kecuali untuk pengujian $\mathrm{Na}$, memiliki nilai $\mathrm{u}$-test 1,95 $>\mathrm{u}>1,64$ yang berarti bahwa hasil dilaporkan kemungkinan tidak berbeda secara signifikan dengan nilai sertifikat.[4] Hal ini menunjukkan bahwa metode analisis yang dilakukan pada penelitian ini valid. 
Tabel 2. Hasil kontrol mutu internal metode dengan NIST SRM 2711a Montana Soil.

\begin{tabular}{|c|c|c|c|c|c|c|c|}
\hline \multirow[b]{2}{*}{ unsur } & \multicolumn{2}{|c|}{ Sertifikat ${ }^{[6]}$} & \multicolumn{2}{|c|}{ Hasil analisis } & \multirow[b]{2}{*}{ Bias relatif $(\%)$} & \multirow[b]{2}{*}{ u-test score } & \multirow[b]{2}{*}{$\begin{array}{c}\text { Rasio } \\
\text { (Hasil/sertifikat) }\end{array}$} \\
\hline & $\begin{array}{l}\text { Nilai } \\
(\mathrm{mg} / \mathrm{kg})\end{array}$ & $\begin{array}{c}\text { Ketidak } \\
\text { pastian }( \pm)\end{array}$ & $\begin{array}{l}\text { Nilai } \\
(\mathrm{mg} / \mathrm{kg})\end{array}$ & $\begin{array}{c}\text { Ketidak } \\
\text { pastian( } \pm \text { ) }\end{array}$ & & & \\
\hline $\mathrm{Fe}(\%)$ & 2,89 & 0,06 & 2,98 & 0,22 & 3,1 & 0,39 & 1,03 \\
\hline $\mathrm{Na}(\%)$ & 1,14 & 0,03 & 1,07 & 0,0234 & 6,2 & 1,86 & 0,94 \\
\hline $\mathrm{Ca}(\%)$ & 2,42 & 0,06 & 2,508 & 0,005 & 3,6 & 1,46 & 1,04 \\
\hline $\mathrm{K}(\%)$ & 2,53 & 0,10 & 2,418 & 0,003 & 4,4 & 1,12 & 0,96 \\
\hline $\mathrm{Ti}(\%)$ & 0,317 & 0,008 & 0,324 & 0,002 & 9,5 & 0,85 & 1,02 \\
\hline As & 105 & 8 & 101 & 5 & 3,9 & 0,45 & 0,96 \\
\hline $\mathrm{Ba}$ & 730 & 15 & 731,49 & 8,97 & 0,2 & 0,09 & 1,00 \\
\hline $\mathrm{Cr}$ & 52,30 & 2,90 & 53,49 & 1,19 & 2,3 & 0,38 & 1,02 \\
\hline $\mathrm{Hg}$ & 7,42 & 0,18 & 7,22 & 0,38 & 2,7 & 0,48 & 0,97 \\
\hline $\mathrm{Co}_{0}$ & 9,89 & 0,18 & 9,63 & 0,23 & 2,6 & 0,89 & 0,97 \\
\hline
\end{tabular}

Untuk mengetahui komposisi unsur dalam sampel abu vulkanik, telah dilakukan analisis kualitatif dan kuantitatif dengan metode AAN. Hasil analisis ditampilkan pada Gambar 2 sampai dengan Gambar 5. Unsur terdeteksi dapat dikelompokkan atas unsur-unsur makro (konsentrasi $>1000 \mathrm{mg} / \mathrm{kg}$ ) meliputi $\mathrm{Na}, \mathrm{Al}$,
$\mathrm{Ca}, \mathrm{Fe}, \mathrm{Mg}$, Ti dan Mn, unsur-unsur mikro (konsentrasi < $500 \mathrm{mg} / \mathrm{kg}$ ) U, Hg, Hf, Sb, Co, Cs, Rb, V, As, Zn, Cr termasuk unsur logam tanah jarang $\mathrm{Eu}, \mathrm{Yb}, \mathrm{Tb}, \mathrm{Lu}, \mathrm{Ce}$, Dy dan $\mathrm{Sc}$ seperti tercantum dalam Tabel 2. Konsentrasi unsur-unsur ini bervariasi pada tiap lokasi sampling.

Tabel 3. Kandungan unsur makro dan mikro dalam abu vulkanik

\begin{tabular}{|c|c|c|}
\hline Kelompok & Unsur & Kisaran Konsentrasi \\
\hline Makro & & $\%$ berat \\
\hline & Al & $10,45-13.37$ \\
\hline & $\mathrm{Fe}$ & $4,44-8,79$ \\
\hline & $\mathrm{Na}$ & $2,55-3,35$ \\
\hline & $\mathrm{Ca}$ & $1,03-8,82$ \\
\hline & Mg & $0,61-1,75$ \\
\hline & $\mathrm{Ti}$ & $0,31-0,58$ \\
\hline & Mn & $0,12-0,17$ \\
\hline Mikro & & $\mathrm{mg} / \mathrm{kg}$ \\
\hline & $\mathrm{Ba}$ & $453,73-668,79$ \\
\hline & V & $105,77-209,68$ \\
\hline & $\mathrm{Zn}$ & $52,41-194,42$ \\
\hline & $\mathrm{Sb}$ & $39,77-129,95$ \\
\hline & $\mathrm{Rb}$ & $24,62-74,35$ \\
\hline & $\mathrm{La}$ & $17,10-22,88$ \\
\hline & $\mathrm{Ce}$ & $13,50-42,72$ \\
\hline & Sc & $7,89-13,09$ \\
\hline & $\mathrm{Co}$ & $8,30-10,90$ \\
\hline & As & $4,24-7,81$ \\
\hline & $\mathrm{Cs}$ & $3,37-8,58$ \\
\hline & Dy & $1,19-9,15$ \\
\hline & $\mathrm{Hf}$ & $3,04-4,21$ \\
\hline & $\mathrm{Yb}$ & $1,84-3,51$ \\
\hline & $\mathrm{Hg}$ & $0,78-2,59$ \\
\hline & $\mathrm{U}$ & $1,24-1,88$ \\
\hline & Eu & $0,86-1,23$ \\
\hline & Tb & $0,69-1,03$ \\
\hline & Lu & $0,36-0,54$ \\
\hline
\end{tabular}


Dari Gambar 2 dapat diketahui distribusi unsur-unsur makro Al, Fe, $\mathrm{Na}, \mathrm{Ca}, \mathrm{Mg}, \mathrm{Ti}$ dan Mn dalam abu vulkanik dari ke-10 lokasi sampling. Konsentrasi Al berkisar antara 4,44-8,79\% terrendah pada L-4 dan tertinggi pada L-8. Konsentrasi unsur Fe antara 4,44-8,79\% terrendah pada L-6 dan tertinggi di L-8. Na dengan konsentrasi antara 2,553,35\%, terrendah di L-10 dan tertinggi di L-4. Konsentrasi Ca 1,03-8,82\%, terrendah di L-6 dan tertinggi di L-8. Konsentrasi Mg 1,038,82, terrendah di L-7 dan tertinggi di L-1. Konsentrasi Ti 0,31-0,58, terrendah di L-6 dan tertinggi di L8 dan konsentrasi Mn 0,120,17\% dengan konsentrasi terrendah di L6 dan tertinggi di L-1. Di sini dapat diketahui bahwa distribusi unsur dalam abu vulkanik adalah acak untuk tiap lokasi. Untuk lokasi L-6 (Desa Ngemplak Seneng Kecamatan Manisrenggo Klaten) yang berjarak $15 \mathrm{~km}$ dari gunung merapi, memiliki kandungan unsur $\mathrm{Fe}, \mathrm{Ca}$, Ti dan Mn dalam abu vulkan relatif lebih rendah bila dibandingkan dengan sampel abu vulkan yang diambil dari lokasi sampling lainnya.

Dengan mengetahui distribusi unsur makro di dalam abu vulkanik dan merujuk hasil uji komposisi kimia tanah abu vulkanik Gunung Merapi Yogyakarta yang dilakukan oleh Balai Teknik Kesehatan Lingkungan (BKTL), 1994 Yogyakarta yang memberikan hasil sebagai berikut : $\mathrm{SiO} 2$ (54.56 \%), Al2O3 (18.37\%), Fe2O3 (18.59\%), $\mathrm{CaO}$ (8.33 \%), $\mathrm{MgO}$ (2.45 \%), $\mathrm{Na} 2 \mathrm{O}(3.62 \%), \mathrm{K} 2 \mathrm{O}(2.32 \%), \mathrm{MnO}(0.17$

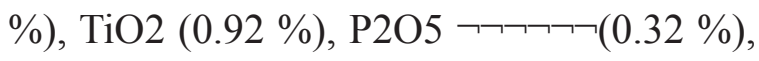
H2O (0.11 \%), HD (0.2 \%). Hal ini selaras dengan hasil analisis yang dilakukan dalam penelitian ini, yaitu abu vulkanik pasca erupsi 2010, memiliki kandungan Al cukup tinggi. Kondisi ini menunjukkan bahwa vulkanik Gunung Merapi memiliki potensi untuk dapat dimanfaatkan sebagai material keramik berbasis allumino silikat, [6] sehingga abu vulkanik memiliki nilai ekonomi.

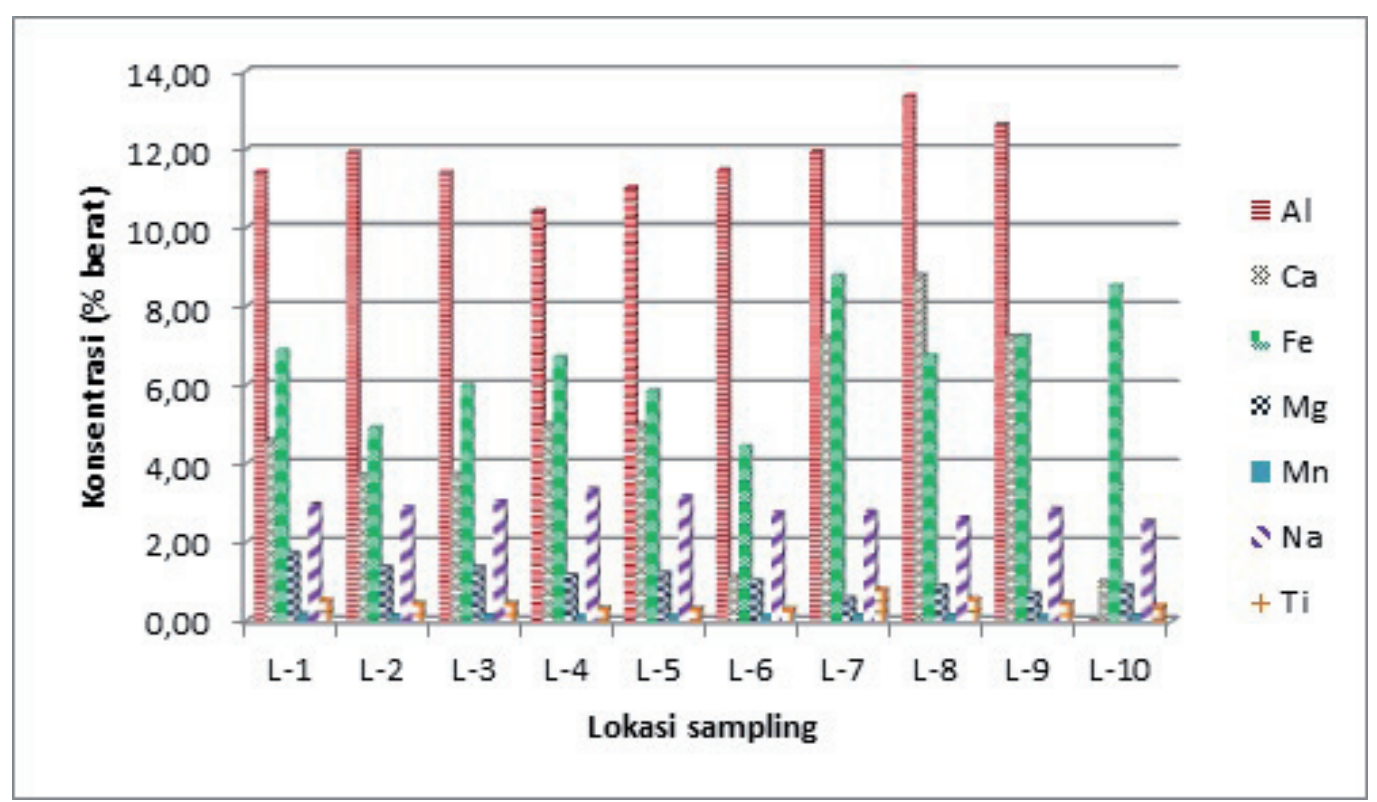

Gambar 2. Distribusi unsur makro Al, $\mathrm{Ca}, \mathrm{Fe}, \mathrm{Mg}, \mathrm{Mn}, \mathrm{Na}$ dan Ti dalam abu vulkanik Pada lokasi titik sampling berbeda 
Pada Gambar 3 dan 4 ditunjukkan histogram distribusi unsur tanah jarang $\mathrm{Yb}, \mathrm{Eu}, \mathrm{Tb}, \mathrm{Lu}$ $\mathrm{Ce}, \mathrm{Sc}$ dan Dy. Unsur-unsur ini termasuk unsur mikro di dalam tanah. Logam tanah jarang tidak ditemukan berupa unsur bebas dalam lapisan kerak bumi tetapi berbentuk paduan membentuk senyawa kompleks. Pengetahuan yang kurang tentang logam tanah jarang menyebabkan logam ini belum banyak mendapat perhatian. Logam tanah jarang memiliki nilai ekonomi dibutuhkan untuk industri seperti telepon selular, televisi flat, komputer, green industry dan mobil listrik. Saat ini China sebagai pemasok logam tanah jarang di dunia sudah mulai mengurangi jumlah pasokannya untuk industri global, kondisi ini merupakan peluang bagi Indonesia untuk mulai memanfaatkan logam tanah jarang yang banyak terkandung di sini.

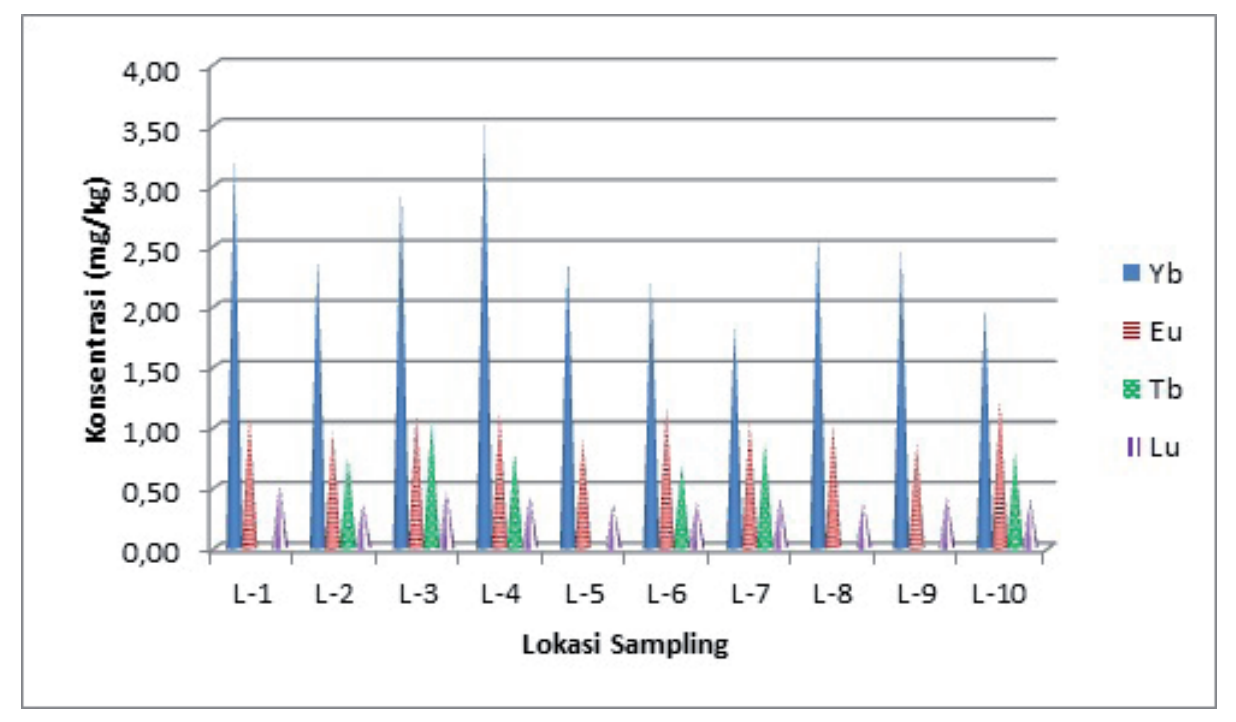

Gambar 3. Distribusi unsur tanah jarang Yb, Eu, Tb dan Lu dalam abu vulkanik Pada lokasi titik sampling berbeda

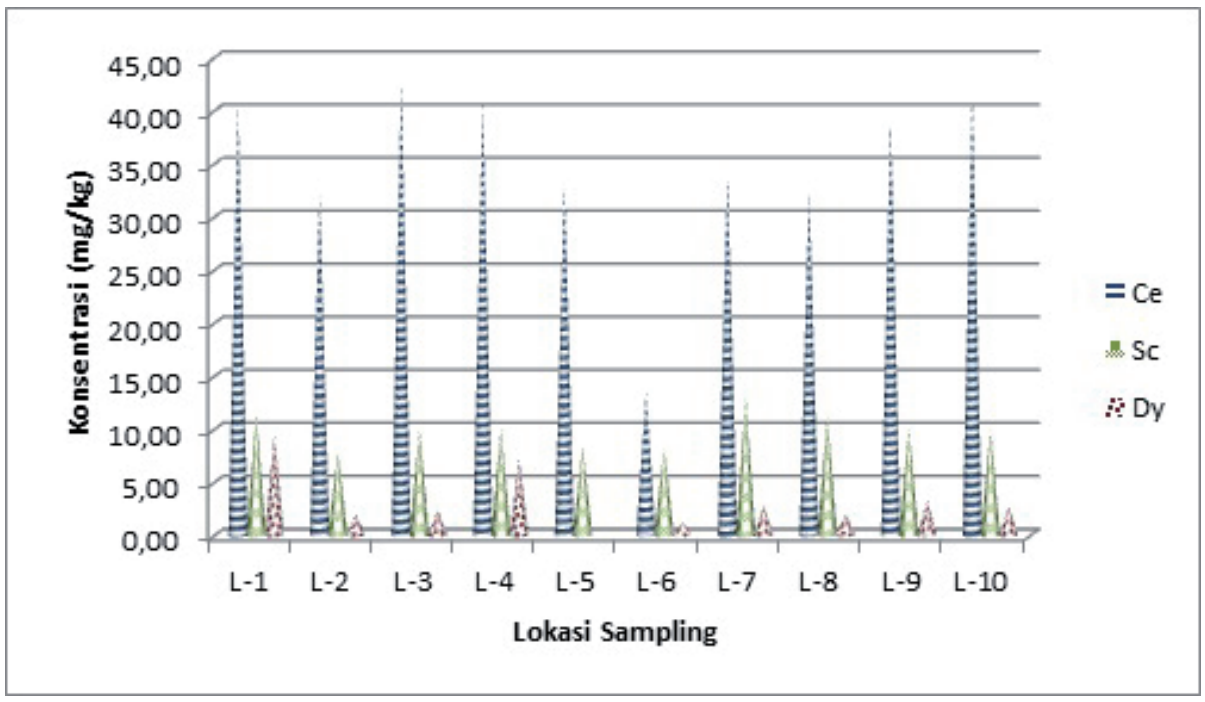

Gambar 4. Distribusi unsur tanah jarang Ce, Sc dan Dy dalam abu vulkanik Pada lokasi titik sampling berbeda 


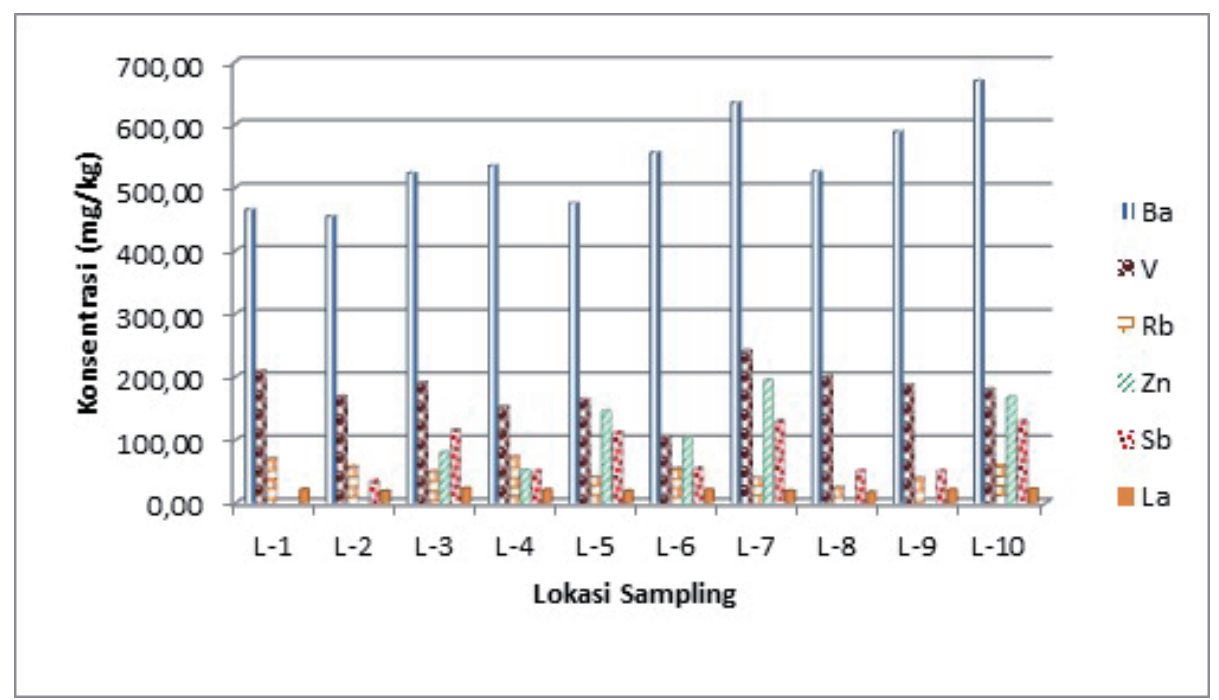

Gambar 5. Distribusi unsur mikro Ba, V, Rb, Zn, Sb dan La dalam abu vulkanik Pada lokasi titik sampling berbeda

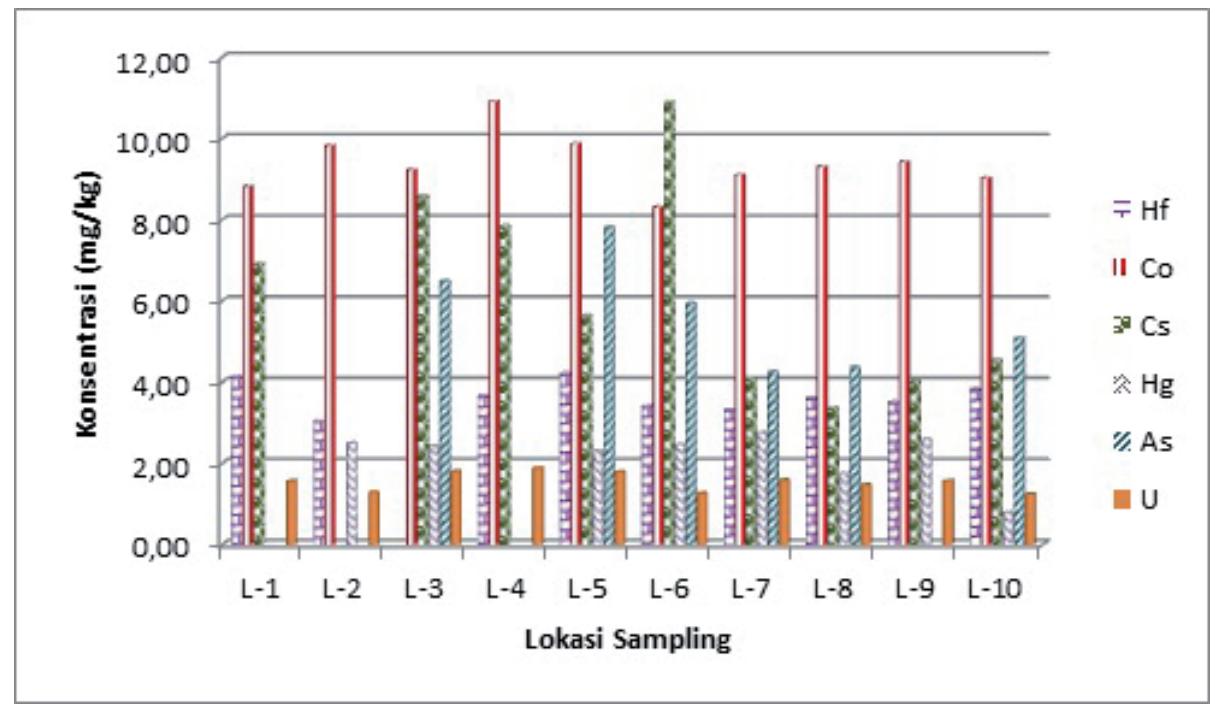

Gambar 6. Distribusi unsur mikro Hf, Co, Cs, Hg, As dan U dalam abu vulkanik Pada lokasi titik sampling berbeda

Pada Gambar 5 dan 6 memperlihatkan histogram distribusi unsur mikro lainnya di dalam abu vulkanik. Unsur Zn tidak terdeteksi pada semua lokasi sampling, demikian juga unsur As. Pada L-1, L-2 dan L-9 tidak terdeteksi unsur Zn dan As, demikian juga dengan unsur $\mathrm{Cr}$ hanya terdeteksi di dua lokasi sampling, yaitu L-4 dan L-5 dan Cr ini tidak digambarkan dalam histogram.
Sedangkan untuk unsur lainnya seperti $\mathrm{Ba}$, $\mathrm{Sb}, \mathrm{V}, \mathrm{Co}$ dan Hf hampir terdeteksi di semua lokasi sampling. Unsur-unsur ini memiliki konsentrasi dengan komposisi tidak jauh berbeda dengan komposisi unsur mikro dalam kerak bumi menurut Mason dalam Alloway BJ dan Ayres DC.[7] Hanya saja pada abu vulkanik terdeteksi adanya unsur As dan $\mathrm{Hg}$ yang merupakan logam berat toksik. 
Tabel 4. Berbagai unsur yang terdapat dalam kerak bumi menurut Mason

\begin{tabular}{|c|c|c|c|}
\hline Unsur Makro & Kuantitas (mg/kg) & Unsur Mikro & Kuantitas $(\mathrm{mg} / \mathrm{kg})$ \\
\hline $\mathrm{Al}$ & 81.300 & $\mathrm{~V}$ & 135 \\
$\mathrm{Fe}$ & 50.000 & $\mathrm{Cr}$ & 100 \\
$\mathrm{Ca}$ & 36.300 & $\mathrm{Rb}$ & 90 \\
$\mathrm{Na}$ & 28.300 & $\mathrm{Ce}$ & 60 \\
$\mathrm{~K}$ & 25.900 & $\mathrm{La}$ & 30 \\
$\mathrm{Mg}$ & 20.900 & $\mathrm{Co}$ & 25 \\
$\mathrm{Mn}$ & 1.000 & $\mathrm{Sc}$ & 22 \\
& & $\mathrm{Th}$ & 7,2 \\
& & $\mathrm{Yb}$ & 3,4 \\
& & $\mathrm{Cs}$ & 3 \\
& & $\mathrm{Hf}$ & 3 \\
& & $\mathrm{Br}$ & 2,5 \\
& & $\mathrm{Eu}$ & 1,2 \\
\hline
\end{tabular}

Komposisi unsur dalam abu vulkanik apabila dibandingkan dengan komposisi unsur dalam kerak bumi menurut Mason dalam Alloway BJ dan Ayres DC, adalah sesuai yaitu apabila diurutkan dari komposisi tertinggi Al, Fe, $\mathrm{Ca}, \mathrm{Na}, \mathrm{Mn}$ dan seterusnya. Demikian juga apabila dilihat konsentrasinya tidak berbeda jauh seperti halnya kandungan alamiah unsur di dalam kerak bumi. Berarti penyebaran abu vulkanik di tanah permukaan mestinya tidak memberi dampak ekstrim terhadap perubahan komposisi unsur pada tanah tersebut, justru akan memperbaiki komposisi hara pada lahan pertanian yang karenA penanaman semakin berkurang dan dengan penambahan abu vulkanik ini akan membuat tanah semakin subur.

Dari hasil análisis abu vulkanik Gunung Merapi, dapat diketahui bahwa abu ini kaya akan unsur hara yang sangat bermanfaat bagi pertanian, sehingga adanya abu vulkanik ini dapat meningkatkan kandungan cadangan nutrisi tanah yang berguna untuk meningkatkan produktivitas tanah untuk pertanian. Secara keseluruhan jenis unsur-unsur terdeteksi dalam abu vulkanik merupakan unsur logam berat yaitu logam dengan massa jenis lima atau lebih, dengan nomor atom 22 sampai dengan 92. Dari sejumlah unsur logam berat yang perlu diperhatikan adalah $\mathrm{Pb}, \mathrm{Hg}, \mathrm{Cd}$, As dan Cr. Hal ini berkaitan erat dengan sifat toksik dari logam tersebut yang dapat mengganggu kesehatan manusia. Dari hasil penelitian yang dilakukan oleh Suriadikarta dkk [8] menunjukkan bahwa kandungan $\mathrm{Pb}$ dan Cd dalam abu vulkanik erupsi Gunung Merapi cukup rendah $\mathrm{Cd}$ 0,0-0,03 mg/kg dan $\mathrm{Pb} 0,0-0,5 \mathrm{mg} / \mathrm{kg}$ dan kondisi ini cukup aman untuk pengembangan pertanian. Dalam penelitian ini unsur $\mathrm{Hg}$ terdeteksi hampir pada semua lokasi sampling kecuali L-1 dan L-4. Konsentrasi $\mathrm{Hg}$ berkisar antara 0,78-2,79 $\mathrm{mg} / \mathrm{kg}$, terrendah L-10 dan tertinggi L-7, konsentrasi As 4,24-7,81 mg/kg terrendah L-7 dan tertinggi L-5. Untuk menentukan batasan unsur logam berat dalam tanah tidak bisa menggunakan peraturan pemerintah yang ada, karena dalam tanah sendiri sudah ada logam berat yang disebut harga cacah latar yang nilainya berbeda untuk setiap jenis tanah atau batuan. 
Abu vulkanik ini tersebar pada daerah yang cukup luas hingga pada radius lebih dari 20 km dari titik pusat Gunung Merapi berada dan menutup lahan yang ada di daerah tersebut. Kondisi ini akan mengganggu kualitas komponen lingkungan yang ada, terutama dengan adanya logam-logam berat yang bersifat toksik. Dengan diketahuinya jenis unsur dan distribusinya, tentunya data akan sangat berguna bagi pertimbangan pemanfaatan jangka panjang peruntukan abu vulkanik tersebut.

Jumlah yang melimpah abu vulkanik dan pasir dari peletusan Gunung Merapi dan terdeteksinya beberapa logam berat di dalamnya dapat digunakan sebagai bahan pertimbangan dalam pemanfaatan material tersebut dengan tepat. Dari penelitian yang dilakukan Lasino dkk[9], menunjukkan bahwa campuran abu vulkanik 30\% dan pasir, baik digunakan untuk mortar dan beton. Dengan adanya logam berat di dalam abu vulkanik, maka penggunaannya untuk bahan bangunan jauh lebih aman.

\section{KESIMPULAN}

Dari penelitian yang telah dilakukan dapat disimpulkan bahwa abu vulkanik dari Gunung Merapi mengandung unsur-unsur makro $\mathrm{Na}, \mathrm{Fe}, \mathrm{Ca}, \mathrm{Al}$ dan $\mathrm{Mn}$, unsur tanah jarang $\mathrm{Eu}, \mathrm{Yb}, \mathrm{Tb}, \mathrm{Lu}, \mathrm{Ce}, \mathrm{Dy}$ dan $\mathrm{Sc}$ dan unsur mikro lainnya $\mathrm{U}, \mathrm{Hg}, \mathrm{Hf}, \mathrm{Sb}, \mathrm{Co}, \mathrm{Cs}, \mathrm{Rb}$, V, As, Zn, Cr. Keberadaan logam berat bersifat toksik $\mathrm{Hg}$, As, Cr perlu diperhatikan dalam pemaanfatan abu tersebut karena berkaitan dengan kesehatan manusia dan lingkungan. Pemanfaatan abu merapi untuk bahan bangunan dan material keramik jauh lebih aman. Kandungan unsur hara dalam abu vulkanik, membuat abu ini baik digunakan untuk pertanian.

\section{UCAPAN TERIMAKASIH}

Ucapan terima kasih penulis sampaikan kepada Dr Agus Taftazani yang telah membantu dalam melakukan dan menyediakan sampel sehingga penelitian ini dapat dilakukan.

\section{DAFTAR PUSTAKA}

1. Gunung Merapi, www.indovolcano. com/gunung-merapi-yogyakarta, diunduh 5 September 2011.

2. SUDARYO dan SUTJIPTO (2009), Identifikasi Dan Penentuan Logam Pada Tanah Vulkanik Di Daerah Cangkringan Kabupaten Sleman Dengan Metode Analisis Aktivasi Neutron Cepat, Sekolah Tinggi Teknologi Nuklir - Batan Yogyakarta.

3. NOFIA H, NITA H, SUNARDI dan YOHANNES SARDJONO, Aplikasi Teknologi Nuklir Untuk Penentuan Unsur Abu Vulkanik Gunung Merapi Pasca Erupsi 2010 dengan AANC, Proseding Seminar Nasional ke-17 Teknologi dan Keselamatan PLTN serta Fasilitas Nuklir Yogyakarta, 2011, ISSN 0845-2910.

4. IAEA. Summary Report of the Proficiency Test for the IAEA Project RAS/2/010: Quality Assurance and Quality Control of Nuclear Analytical Techniques, Seiberdorf, 03 January, 2009. 
5. NIST Certificate of Analysis Standard Reference Material Montana Soil, Gaithersburg,MD 20899,USA, Certificate Issue date 22 May 2009.

6. BPPT manfaatkan abu vulkanik Gunung merapi Bromo sebagai bahan Glasir, www. BPPT.go.id diunduh 19 April 2012.

7. MASON dalam ALLOWAY B.J. dan AYRES D.C., Chemical principle of environmental pollution, Blakie Academic \& Professional, Glasgow G64-2NZ, 1994, UK.
8. SURIADIKARTA dkk, Identifikasi Sifat Kimia Abu Volkan, Tanah dan Air di Lokasi Dampak Letusan Gunung Merapi, www. Balittanah. litbang.deptan.go.id, diunduh 18 April 2012.

9. LASINO, BAMBANG S dan DANI CAHYADI, Pemanfaatan Pasir dan Debu Merapi sebagai Bahan Konstruksi dalam Mendukung Pembangunan Infrastruktur dan Meningkatkan Nilai Guna ahar Vulkanik, Pusat Penelitian dan Pengembangan Permukiman Kementerian Pekerjaan Umum, www. bsn.go.id, diunduh 20 April 2012 